\title{
Spin-off use of adverse events data: why and how. The case of FDA's MAUDE
}

\section{By P Malataras ${ }^{1}$ and $\mathbf{N}$ Pallikarakis ${ }^{2}$}

${ }^{1}$ University of Patras

${ }^{2}$ Institute of Biomedical Technology, INBIT

\section{ABSTRACT}

Objectives: This paper attempts to measure the impact of the second stage exploitation of FDA's MAUDE database on patient safety, technology assessment and other scientific fields.

Methods: Five bibliographic databases have been queried with the terms "Manufacturer and User Facility Device Experience Database" and "FDA AND MAUDE". A number of eligibility criteria where applied on the results, which led to a final group of 117 papers. An extensive study of these publications resulted to a number of interesting findings.

Results: The results concern the evolution of the database exploitation over time, and are examined according to the device groups that the identified papers are referring to, the research goals of these papers, the reasons that led the authors of these papers to use MAUDE data and finally how these data were used within their research methodology.

Conclusions: Patient safety and technology assessment are two of the scientific fields on which MAUDE database has the greatest impact. On average, more than 10 peer-reviewed papers each year involve MAUDE data as a mean to reach their research goals. This proves that MAUDE is an exploitable and valuable data source for research in these scientific fields.

Keywords - Medical Devices, MAUDE, Adverse Events Reports, Patient Safety, Health Technology Assessment.

\section{INTRODUCTION}

Patient safety, health technology assessment and medical device vigilance are fields that heavily rely on data availability. They need valid data from various sources in order to extract useful information. A significant source of data for medical devices (MDs) appears to come from the medical devices vigilance and post-market surveillance mechanisms that are imposed by the relevant regulatory systems, in most part of the world. The Food and Drug Administration (FDA) Manufacturer and User Facility Device Experience (MAUDE) database is such a source.
Millions of medical devices are used today in various places (hospitals, clinics, houses, etc.) and thousands of new models enter the market every year. Undoubtedly these MDs have a significant contribution to the improvement of the healthcare services provided. However, medical technology, like any other technology, is not risk free. There are numerous cases where devices have been recalled because of their involvement in adverse incidents compromising patients' health or cases where a "promising" innovative approach has to be withdrawn after a 
relatively short period of use, because it is not proven as safe as expected. ${ }^{1,2,3,4}$

The largest MDs markets today (USA, EU, Japan, etc.) are ruled by regulatory frameworks (Regulations, laws, directives, guidelines) according to which a medical device has to comply with specific safety provisions in order to enter these markets ${ }^{5,6}$. One safety requirement, common to all these frameworks, is the adverse event reporting system or vigilance system that follows the medium and high risk devices, after they have entered the market, in parallel with the post-market surveillance., 6, 7

A MDs vigilance reporting system aims to increase patient safety by preventing the recurrence of reported adverse events. This is achieved by mandating users and manufacturers of medical devices to report to the health authorities, incidents where a medical device contributes to an adverse event. According to this mechanism, whenever a medical device is potentially contibuted in a death or injury of a patient or user, the manufacturer has to report this event and assess if corrective actions should be taken. In parallel, a user reporting system encourages users to report to the manufacture and/or to authorities any such incident that comes to their attention. The principal purpose of the medical devices vigilance and user reporting systems is to improve the safety of patients, users and others, by reducing the likelihood of reoccurrence of a similar event elsewhere in the future. This is to be achieved by the evaluation of reported incidents and, where appropriate, dissemination of information, which could be used to prevent such repetitions, or to alleviate the consequences of such incidents.

USA is the biggest medical device market ${ }^{8,9}$ and FDA, as the relevant organization for market surveillance, is also responsible for medical devices vigilance. FDA has implemented since the 1990s a database called Manufacturer and User Facility Device Experience Database ${ }^{10}$ for reporting of medical devices related with adverse events. Nowadays, this database receives more than 800.000 reports annually. ${ }^{11}$

Today, MAUDE contains more than 4 million medical device reports (MDRs) ${ }^{11}$ of suspected device-associated deaths, serious injuries and malfunctions as well as other non-conformities such as packaging and labelling problems, unsterilized delivery etc. MAUDE contains MDRs filed by manufacturers and importers from August 1996 to present, all mandatory user facility reports from 1991 to present and voluntary reports filed after June $1993^{12}$. A portion of the database is open to the public, providing valuable information on MDs safety. It is accessible through the FDA's website (www.fda.gov) and can be queried through a search form. In addition, all main datasets are provided to the public as text files importable to common databases.

After an evaluation process, the high volume MDRS or the ones involved with a death are investigated by FDA and in many cases this investigation leads to corrective actions, with obvious benefits for the safety of both patients and users. At a second stage, this huge amount of data appears to be a valuable source for further research. Retrospective analysis studies, data extraction techniques and other scientific use of these data, offer spin-off benefits to patient safety, medical device technology assessment and other scientific fields ${ }^{13,14 .}$

This study attempts to measure quantitatively and qualitatively the second stage exploitation of MAUDE and the impact of this exploitation on scientific research.

\section{MATERIALS AND METHODS}

Five international bibliographic databases (ScienceDirect, Journals@Ovid Full Text, Pubmed, Web of Science and Scopus) have been queried with the terms "Manufacturer and User Facility Device Experience Database" and "FDA AND MAUDE" in order to find all publications that contain these terms. The databases were queried in January 2015. The results of these queries were consolidated through the removal of duplicates, which led to an initial number of 1.016 unique publications. (The results from each database appear in Table 1).

This set of results was filtered according to the publication type, language and publication time so as to keep only peer-reviewed papers, written in English, from 2005 to 2014. Books, editorials, commentaries, letters, comments on a paper, publications in conference proceedings, etc., were excluded from the final selection. After filtration, 381 scientific papers remained.

The next step was to extract out of these 381 papers the ones that have used directly data from MAUDE. This 
TABLE 1. Bibliographic Search Results

\begin{tabular}{|c|c|c|}
\hline $\begin{array}{l}\text { Bibliographic } \\
\text { Database }\end{array}$ & $\begin{array}{l}\text { MAUDE AND } \\
\text { FDA }\end{array}$ & $\begin{array}{c}\text { “Manufacturer and } \\
\text { User Facility Device } \\
\text { Experience Database” }\end{array}$ \\
\hline ScienceDirect & $322 \mathrm{a}$ & 269 \\
\hline $\begin{array}{l}\text { Journals@Ovid } \\
\text { Full Text }\end{array}$ & $196^{\mathrm{a}}$ & 175 \\
\hline Pubmed & 54 & 42 \\
\hline Web of Science & 49 & 41 \\
\hline Scopus & $209^{\mathrm{a}}$ & 322 \\
\hline $\begin{array}{l}\text { Total (without } \\
\text { duplicates) }\end{array}$ & 631 & 604 \\
\hline \multicolumn{3}{|c|}{$\begin{array}{c}{ }^{a} \text { The search has been performed with proximity indicators } \\
\text { (MAUDE w/10 FDA) or (MAUDE ADJ10 FDA) }\end{array}$} \\
\hline
\end{tabular}

selection led to a final group of 117 papers. Among these papers, there were 4 where the authors searched the MAUDE database but the results were found to be irrelevant to this work. However, these 4 papers were decided to be included in the final group because, although they finally did not use any data from MAUDE, they took into consideration the content of the database. The list of 117 papers appears in the Reference section (Ref: 14-25, 28, 31, 33-135).

It should be mentioned that among the 264 excluded papers, more than 50 referred to MAUDE data, but this reference was either limited to a single comment about one or two cases or indirect, using the results of other papers that had used the original data.

The last step was to study again in more detail the final group of these 117 papers, focusing on the device groups that these papers referred to, the evolution of the database exploitation with time, the research goals of these papers, the reasons that led the authors of these papers to use MAUDE data, how they finally used these data within their research methodology, etc. The flowchart for the query methodology is shown in Figure 1.

The bibliographic search results were processed initially with the Mendeley desktop references management software and later with Microsoft Excel.

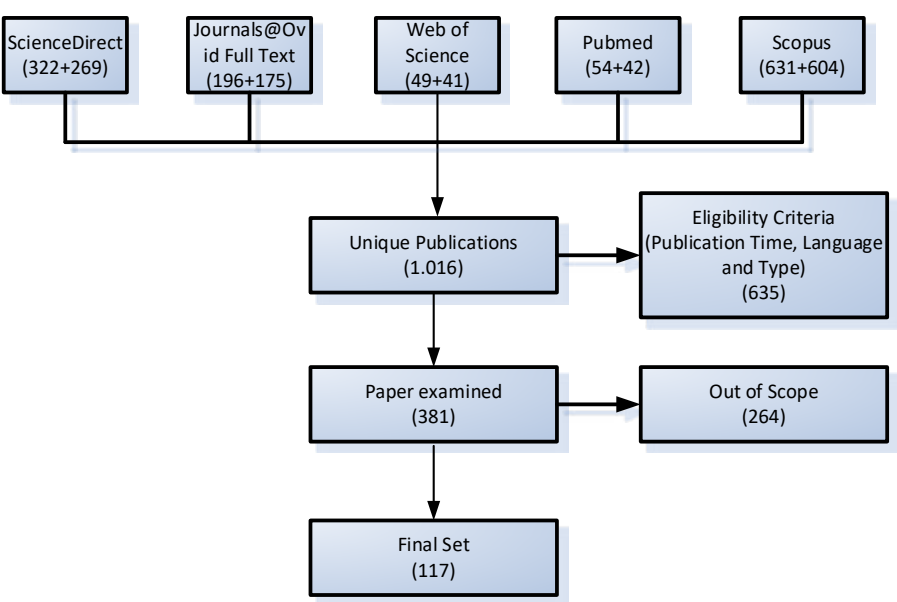

FIGURE 1. PRISMA flow chart for FDA MAUDE system search

\section{RESULTS}

The analysis of the final set of 117 papers revealed the following:

A) Since MAUDE is a database containing MDRs, each record is related with a medical device. Hence retrieval of data for the second stage usage is also related with medical devices. The analysis carried out identified the device groups that were used as a reference in the papers. These device groups were grouped, where applicable, into more generic device categories. It should be mentioned that although 24 papers were focused exclusively on a device type rather than on a group as a whole, only the device group was considered for the purposes of this analysis.

TABLE 2. Number of Papers per Device Group

\begin{tabular}{|l|c|}
\hline Cardiology Devices & $\mathbf{2 9}$ \\
\hline Stents & 9 \\
\hline Implantable Cardioverter-Defibrillators & 7 \\
\hline Vena Cava Filters & 6 \\
\hline Automated External Defibrillators & 2 \\
\hline Angioplasty Catheters & 1 \\
\hline Arterial Closure Devices & 1 \\
\hline Catheter Introducing Sheaths & 1 \\
\hline Catheters & 1 \\
\hline Vascular Closure Systems & 1 \\
\hline
\end{tabular}




\begin{tabular}{|l|c|}
\hline Implantable Devices & $\mathbf{2 2}$ \\
\hline Meshes & 6 \\
\hline Septal Occluders & 4 \\
\hline Cochlear Implants & 4 \\
\hline BMP2 protein & 3 \\
\hline Breast Implants & 1 \\
\hline Cerebrospinal Fluid Valves & 1 \\
\hline Heart Valves & 1 \\
\hline Silicone-Polyurethane Copolymers & 1 \\
\hline Spinal Cord Stimulator & 1 \\
\hline Endoscopy Devices & $\mathbf{1 4}$ \\
\hline Endoscopy-General & 4 \\
\hline Endometrial Ablation Devices & 3 \\
\hline Endoscopic Stapling & 1 \\
\hline ERCP & 1 \\
\hline Gastrointestinal Endoscopy & 1 \\
\hline Microwave Endometrial Ablation & 1 \\
\hline Mucosal Ablation Devices & 1 \\
\hline Radiofrequency Ablation & 1 \\
\hline Various & $\mathbf{6}$ \\
\hline Laparoscopy Devices & 1 \\
\hline Hem-o-lok & $\mathbf{4}$ \\
\hline Laparoscopic Morcellator & 1 \\
\hline Laparoscopic Trocar & 1 \\
\hline Various & 1 \\
\hline Infusion Devices -Pumps & 1 \\
\hline Infusion Devices & 1 \\
\hline Insulin Pumps & 1 \\
\hline Infusion Pumps & 1 \\
\hline Prosthesis & 1 \\
\hline Artificial Discs & 1 \\
\hline Hip Prosthesis & 1 \\
\hline Lumbar Total Discs & 1 \\
\hline Shoulder Prosthesis & 1 \\
\hline
\end{tabular}

\begin{tabular}{|l|l|}
\hline Robot Assisted Surgery & $\mathbf{4}$ \\
\hline Transcervical Sterilization & $\mathbf{4}$ \\
\hline Patient-Controlled Analgesia & $\mathbf{3}$ \\
\hline Stone Extraction Balloons And Baskets & $\mathbf{2}$ \\
\hline Stone Baskets & 1 \\
\hline Stone Extraction Balloons and Baskets & 1 \\
\hline Extracorporeal Oxygenation & 2 \\
\hline Extracorporeal Membrane Oxygenation & 1 \\
\hline Oxygenator & 1 \\
\hline Lasers - General & $\mathbf{2}$ \\
\hline Cosmetic Laser & 1 \\
\hline Lasers & 1 \\
\hline Ambulance Stretcher & $\mathbf{1}$ \\
\hline Bed Rails & $\mathbf{1}$ \\
\hline Breast Pumps & $\mathbf{1}$ \\
\hline Contact Lenses & $\mathbf{1}$ \\
\hline Ethylene vinyl alcohol copolymer & $\mathbf{1}$ \\
\hline Feeding Tubes & $\mathbf{1}$ \\
\hline Glucose Monitors & $\mathbf{1}$ \\
\hline MRI & $\mathbf{1}$ \\
\hline Operating Microscopes & $\mathbf{1}$ \\
\hline Peritoneal Dialysis & \\
\hline Piggybacks & 1 \\
\hline Tanning Units & 1 \\
\hline Papers referring to Various Device & 1 \\
\hline Groups & 1 \\
\hline
\end{tabular}

According to the analysis performed, the general category of Cardiology Devices was the most frequently referred (29 papers), while Implantable Devices (22 papers) and Endoscopy Devices (14 papers) were the next ones. As regards the device groups, Stents ( 9 papers), Implantable Cardioverter-Defibrillators (7 papers), Meshes (6 papers), Vena Cava Filters (6 papers), Septal Occluders (4 papers), and Cochlear Implants (4 papers) were the leaders. Finally, there were 8 papers that have not been included in this part of the analysis, since they used a 


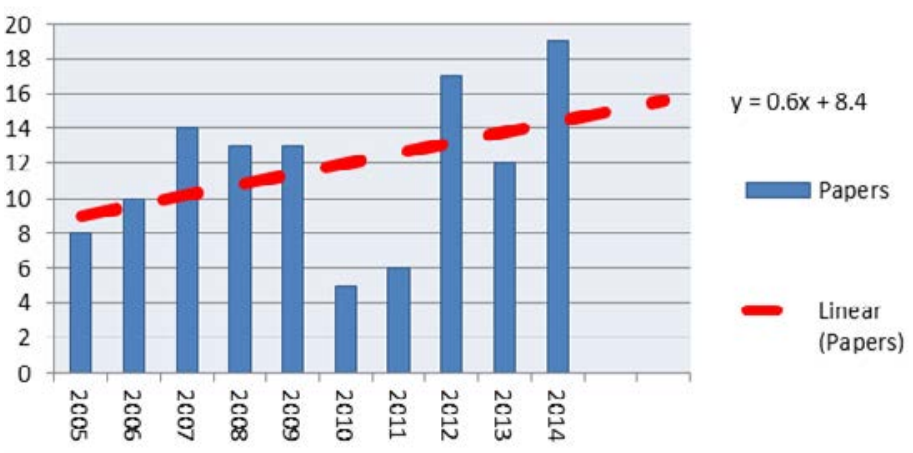

FIGURE 2. Number of papers published each year.

combination of data related with various device groups. The number of papers classified under each group is presented in Table 2.

B) As regards the publication time of these papers, 2014, 2012 and 2007 were the years with the most published papers $(19,17$ and 14 papers respectively). The linear trend line shows that the number of papers that used the MAUDE data increases with time (slope $=0.6$ ). (Figure 2)

C) Although it was difficult and maybe risky to summarize and classify the research objectives of papers covering various scientific areas and subjects, into a few generic objectives' categories, such an attempt was made in order to outline the research orientation of the papers that use data from the MAUDE database.

The most common objectives among these papers were "to review/identify the reported adverse events/complications related with a device group or type" (31 papers), "to evaluate adverse events" (22), "to evaluate design characteristics of a device group or type" (15 papers), "to explain why these events occur" (14 papers), and "to overview a medical technology and/or its performance" (10 papers). Table 3 presents the results of this analysis.

TABLE 3. Research Objectives

\begin{tabular}{|c|c|c|}
\hline Papers' Objectives & $\begin{array}{l}\text { Number } \\
\text { of papers }\end{array}$ & Example of Objective \\
\hline $\begin{array}{l}\text { To review/identify reported adverse events/ } \\
\text { complications }\end{array}$ & 31 & $\begin{array}{l}\text { To collate world reports of adverse events (AEs) resulting from lasers used in } \\
\text { urology }{ }^{15}\end{array}$ \\
\hline To evaluate adverse events/complications & 22 & $\begin{array}{l}\text { To raise awareness of the potential hazard of auricular burns associated with } \\
\text { operating microscope use during otologic surgery }{ }^{16}\end{array}$ \\
\hline $\begin{array}{l}\text { To examine/evaluate design characteristics of } \\
\text { a medical device }\end{array}$ & 15 & We sought to determine if perforation rates are related to cannula design ${ }^{17}$ \\
\hline $\begin{array}{l}\text { To explain why specific adverse events/ } \\
\text { complications occur }\end{array}$ & 14 & $\begin{array}{l}\text { This study was undertaken to analyze bleeding problems with tension-free vaginal } \\
\text { tape (TVT) operations }{ }^{18}\end{array}$ \\
\hline $\begin{array}{l}\text { To overview a medical technology and/or its } \\
\text { performance }\end{array}$ & 10 & $\begin{array}{l}\text { This study sought to determine whether infusion device event logs could support } \\
\text { accident investigation }^{19}\end{array}$ \\
\hline $\begin{array}{l}\text { To assess the frequency and/or severity of } \\
\text { adverse events/complications }\end{array}$ & 8 & $\begin{array}{l}\text { The purpose of this study is to use large databases to assess the frequency and } \\
\text { severity of such complications and compare them with those of surgical atrial septal } \\
\text { defect closure }\end{array}$ \\
\hline To evaluate/test a method or a hypothesis & 7 & $\begin{array}{l}\text { The aim of this article is to evaluate a new system and procedure, dedicated to } \\
\text { oxygenator change-out }\end{array}$ \\
\hline To review a new technology/procedure & 7 & $\begin{array}{l}\text { This document will review the biliary and pancreatic stone extraction devices that } \\
\text { are currently commercially available in the United States }\end{array}$ \\
\hline To discuss regulatory issues & 2 & $\begin{array}{l}\text { The present analysis aimed to compare the } 510(\mathrm{k}) \text { and PMA approvals and } \\
\text { recalls on the basis of the number of devices approved in each group }{ }^{23}\end{array}$ \\
\hline To estimate cost & 1 & $\begin{array}{l}\text { To estimate the rates and costs of intravenous patient-controlled analgesia } \\
\text { (IV PCA) errors from the hospital or integrated health system perspective }\end{array}$ \\
\hline
\end{tabular}


D) Equally difficult was the attempt to examine and classify the purpose for which the MAUDE data were used within those papers. The findings of this analysis were similar with the findings of the analysis of the papers' objectives. In brief, the main reasons for the use of MAUDE data was "to summarize or review adverse events" (53 papers) as well as "to explain why these events occur" (42 papers). Additionally, it was found that 36 papers dealt with the evaluation of adverse events or complications, and 32 papers provided directly suggestions for patient safety measures. Finally, it should be noted that in each paper these data could have been used for more than one purpose. All the findings of this analysis are presented in Table 4. and publications in conference proceedings, which were used on MAUDE data.

The device groups that the papers focused on were mainly cardiology devices (Stents and Implantable Cardioverter-Defibrillator), implantable devices (Meshes and Cochlear implants), endoscopy and laparoscopy devices. It is surprising that high risk device groups that are used widely in hospitals, such as Respirators, Anesthesia Machines, ECG, etc., were not among the devices of this list. One possible reason for this fact is that the researchers have directed their attention to devices that had entered the market within or near the period under examination (drug eluted stents, robot assisted surgery, transcervical sterilization, etc.) or to device groups containing products

TABLE 4. Purposes of MAUDE data use

\begin{tabular}{|l|c|}
\hline The MAUDE data have been used: & $\begin{array}{c}\text { Number of } \\
\text { Papers }\end{array}$ \\
\hline To summarize the adverse events related with a device group or type & 53 \\
\hline To explain why specific adverse events occur & 32 \\
\hline To evaluate adverse events or complications & 36 \\
\hline To suggest patient safety measures & 32 \\
\hline To assess a device group or type & 30 \\
\hline To estimate how frequent is the occurrence of an adverse event or to calculate trends & 30 \\
\hline To assess the safety of a technology or of a medical procedure & 24 \\
\hline To assess the severity of adverse events/complications & 15 \\
\hline
\end{tabular}

\section{DISCUSSION}

The final number of 117 papers that were found to have used MAUDE data cannot be considered as covering the whole spectrum of the respective research activities. The actual range of MAUDE data usage must be considered even greater if it is taken into account that among the publications that were excluded by the present study, there were many papers that a) refer to a unique case from MAUDE, b) use partially or complementarily data from it or c) refer to other papers based on MAUDE data analysis. In addition, it was also found that there were many other kinds of publications, such as books, editorials, which have been involved in serious recalls (Stents, Occluders, Cardioverter, Defibrillators etc. ${ }^{1}$.

The number of papers that use data from MAUDE appears to increase with time, having a time trend with a rate of 0.6 (Figure 1). It is expected that in the near future the second stage exploitation of MAUDE data will further increase given that FDA makes a constant effort to improve the quality of data and their accessibility (Unique Device Identifier, Total Product Life Cycle, Open FDA etc.) $)^{2,3,11}$ 25,26 in combination with the fact that new or improved management and analysis techniques of big data emerge. 
The examination of the papers' research objectives clearly shows that the majority of the papers under consideration contributes directly or indirectly to patient safety by reviewing or summarizing the adverse events/ complications related with a specific device group or type (31 papers), by evaluating adverse events/complications (22 papers), by explaining why these events occur (15 papers) or by assessing the frequency or severity of adverse events (8 papers). Additionally, the contribution to technology assessment is also significant through the evaluation of the devices' design characteristics (14 papers), the overview of a medical technology and its performance (10 papers) and the review of new technology and/or medical procedures (7 papers). Finally, the papers in question have a contribution in other fields too. For example, 7 papers used MAUDE data in order to test or evaluate a method and 2 papers discussed the regulatory issues for medical devices.

The fact that the MAUDE database is a useful source for patient safety purposes is further supported by the examination of the manner in which these data are used in the papers. It was found that MAUDE data have been used among others to summarize the adverse events related to a device or a medical procedure, to explain why adverse events occur and to suggest specific measures. The ultimate goal of the above-mentioned uses was to inform the medical community as well as MD designers and manufactures about the problems that could arise, the likelihood for them to occur, the underlying mechanisms that lead to these complications, the ways to avoid or to deal with these events and the measures to eliminate their consequences. Besides, MAUDE appears to be a useful tool as regards technology assessment too, since its data have been used in order to assess the use of medical technologies and medical devices, as well as to estimate the risk of the utilization of a device or procedure. It is also worth mentioning that from this analysis, it was found that 14 of the papers used the MAUDE database as a source in order to test or evaluate a method, a procedure or a hypothesis. For example, MAUDE data were used to evaluate the role of human factors in acute care equipment decisions ${ }^{27}$ and to examine whether the log files could assist in an accident investigation ${ }^{19}$.
During the papers' analysis, other useful information was also gathered, pertaining to research limitations inserted by the use of MAUDE data as well as to the quality and integrity of these data. In many papers it is mentioned that the MAUDE data and the use of adverse event reports data in general, inserted certain limitations dealing with the reporting rate and the denominator issue ${ }^{28}$. As regards the reporting rate, there is a general belief that not only adverse events are under-reported but there is also a lack of information about the ratio representing the number of adverse events reported versus the number of real events that have occurred. Similarly, there is a lack of baseline numbers (e.g. total number of surgical procedures relevant to a product, total number of specific devices used, etc.) that could be used as denominators. Both these limitations make the data unsuitable for determining rates ${ }^{29,30}$.

Moreover, there was criticism as regards the consistence and quality of the MAUDE data. Some researchers have doubts about their quality, stating that the data provided by FDA are not structured in a common way, are not complete and their accuracy is debatable, thus obstructing the analysis procedures. Others commented that the information and degree of detail contained within these reports are highly variable, making interpretation of the reports difficult and causality often uncertain ${ }^{29,31}$.

During the period 2005-2014, MAUDE data could be searched either by an online search form provided by the FDAs' web site or by downloading them in txt formatted files. The majority of the studies have used the online search form. There were only a few that have used the MAUDE data provided in txt format. This is probably because the insertion of these txt files into a relational database is not an easy task given the amount of data (some tables have more than 3 million rows) and because the txt files need some technical preparatory actions in order to be ready for insertion. It is expected that the openFDA web site (https://open.fda.gov/) which provides capabilities for easier and more comprehensive access to the data in addition with the further use of the database with contemporary big data analysis tools or data mining techniques will lead to a more intense exploitation of MAUDE database. 
Finally, it is worth mentioning the positive impact of the transparency of MAUDE database comparing it with the European Databank on Medical Devices (EUDAMED). In the EU, legislative changes imposed stricter and more detailed monitoring and enforcement requirements for both notified bodies and national competent authorities, in response to increasing safety concerns. Recently, the enforcement of a more rigorous new legislation in the form of two Regulations ${ }^{136,137}$ has been voted by the European Parliament. The use of the European Databank on Medical Devices (EUDAMED), containing regulatory information on MDs available on the EU market, including recalls, is also reinforced. However, regarding the EU user reporting system for medical devices adverse events, there is not an overall collection of the reports submitted to the national competent authorities. This is due to the decentralised structure of the EU regulatory system, in combination with the fact that there is no provision for a centralised collection into the EUDAMED. Additionally, the EU policy that does not allow the public access to all these data, including the recalls, prohibits their analysis by independent researchers.

A research comparing the impact of the transparency of EU vigilance system with the one of FDA for the period 2004-2015, found that there are no papers or reports, even from a central EU body, based on the EUDAMED data ${ }^{138}$. However it is a fact that EUDAMED can provide similar information. As an example, Bliznakov et.al ${ }^{139}$ performed a survey on medical device recalls, concerning only devices using software, based on FDA data for the period 1995-2002. It was found that about $25 \%$ of the recalls studied, were caused by software failures. As might be expected, the proportion of these recalls due to software problems increased, from $17 \%$ in 1995 to 34\% in 2002. Follow up studies ${ }^{140,141}$ revealed that this proportion went up to $40 \%$ in year 2012 . These authors, performed in parallel a survey on recalls caused by software failures using EUDAMED data, and found very similar results. Unfortunately, those results could not be published due to the restrictions on the use of EUDAMED data.

\section{CONCLUSIONS}

FDA provides public access to a portion of its postmarket surveillance database, thus allowing researchers outside FDA to carry out analyses and studies based on the raw data, with a consequent spin-off benefit for public health. The fact that, in spite of the limitations, more than 10 peer-reviewed papers each year use MAUDE data shows that MAUDE is an exploitable and valuable data source.

According to the analysis of the papers, MAUDE database is used mainly for research works related to patient safety and technology assessment compared to other scientific areas. It is also observed that the MAUDE data are mainly used to evaluate devices that are relatively new to the market, or to investigate issues related with these devices. Additionally, it was found that MAUDE is a useful data source when it is required to summarize adverse events related with a device as well as when the reasons that could lead to an adverse event have to be examined. Finally, MAUDE data exploitation increases with time and is expected to be even more intensive in the future.

Undoubtedly, there are improvements that could increase the exploitation of MAUDE database. However, despite limitations, restrictions and criticism, it is a common conclusion among the majority of the papers studied, that the MAUDE database is a useful and valuable tool for patient safety and technology assessment. The benefits resulting from the MAUDE use should be taken into consideration by the EU, so as to move in the direction of enhancing and improving the data collection procedures from the vigilance system as well as to increase the transparency of EUDAMED as explicitly stated in the regulations ${ }^{136,137}$ : "..vigilance and market surveillance should be significantly reinforced, whilst provisions ensuring transparency and traceability regarding medical devices should be introduced, to improve health and safety ... The objectives of the database are to enhance overall transparency, including through better access to information for the public and healthcare professionals .... Additionally individual researchers should be allowed to have access to relevant data, in order to be able to perform similar studies that significantly contribute to equipment improvement and patient safety. 


\section{CONFLICT OF INTEREST}

The authors declare that there is no conflict of interest regarding the publication of this paper.

\section{REFERENCES}

1. FDA. Unsafe and ineffective Devices Approved in the EU that were Not approved in the US. 2012.

2. SORENSON C, DRUMMOND M. Improving Medical Device Regulation: The United States and Europe in Perspective. Vol. 92, Milbank Q. (C) 2014 John Wiley \& Sons, Ltd: (1)London School of Economics and Political Science,; 2014. p. 114-50.

3. Kramer DB, Tan YT, Sato C, Kesselheim AS. Ensuring medical device effectiveness and safety: a cross--national comparison of approaches to regulation. Food Drug Law J. 2014;69(1):1-23, i.

4. Rao S V, Califf RM, Kramer JM, Peterson ED, Gross TP, Pepine $\mathrm{CJ}$, et al. Postmarket evaluation of breakthrough technologies. Am Heart J. 2nd ed. 2008;156(2):201-8.

5. Kramer D, Xu S, Kesselheim A. Regulation of Medical Devices in the United States and European Union. Vol. 366, N Engl J Med. Copyright (C) 2012 Massachusetts Medical Society. All rights reserved.: From Harvard Medical School (D.B.K., S.X., A.S.K.), Cardiovascular Division, Beth Israel Deaconess Medical Center (D.B.K.), and the Division of Pharmacoepidemiology and Pharmacoeconomics, Department of Medicine, Brigham and Women's Hospital (A.S.K.) - all; 2012. p. 848-55.

6. Kramer DB, Tan YT, Sato C, Kesselheim AS. Postmarket Surveillance of Medical Devices: A Comparison of Strategies in the US, EU, Japan, and China. PLoS Med. 2013;10(9):e1001519.

7. Santos IC, Gazelle GS, Rocha L a, Tavares JMR. Medical device specificities: opportunities for a dedicated product development methodology. Expert Rev Med Devices. 3rd ed. 2012;9(3):299-311.

8. Altenstetter C. Medical device regulation in the European Union, Japan and the United States. Commonalities, differences and challenges. Innov Eur J Soc Sci Res. 2012;25(4):362-88.

9. Medtech Europe. The European Medical Technology Industry in Figures What is Medical Technology? [Internet]. 2014. Available from: http://www.eucomed.org/uploads/Modules/ Publications/the_emti_in_fig_broch_12_pages_v09_pbp.pdf

10. MAUDE - Manufacturer and User Facility Device Experience [Internet]. [cited 2015 May 10]. Available from: https://www. accessdata.fda.gov/scripts/cdrh/cfdocs/cfmaude/search.cfm

11. OpenFDA [Internet]. [cited 2015 May 6]. Available from: https:/open.fda.gov/device/event/

12. U.S. Food and Drug Administration. Medical Device Reporting (MDR) [Internet]. [cited 2015 May 10]. Available from:
http://www.fda.gov/MedicalDevices/Safety/ReportaProblem/ default.htm

13. Marinac-Dabic D, Wang B, Hefflin BJ, Duggirala HJ, Mathew TM, Krulewitch CJ. Data sources for medical device epidemiology studies and data mining. In: Medical Device Epidemiology and Surveillance. John Wiley \& Sons, Ltd; 2007. p. 99-125.

14. Torrence ME. Data Sources: Use in the Epidemiologic Study of Medical Devices. Epidemiology. 2002;13(3):S10-4.

15. Althunayan AM, Elkoushy M a, Elhilali MM, Andonian S. Adverse Events Resulting from Lasers Used in Urology. J Endourol. 2013 Apr;28(2):256-60.

16. Latuska R, Carlson M, Neff B, Driscoll C, Wanna G, Haynes D. Auricular Burns Associated With Operating Microscope Use During Otologic Surgery. Otol Neurotol. 2014;35(2):227-33.

17. Johnson SM, Itoga N, Garnett GM, Kilcommons M, Puapong DP, Woo RK. Increased risk of cardiovascular perforation during ECMO with a bicaval, wire-reinforced cannula. J Pediatr Surg. 2014;49(1):46-50.

18. Kölle D, Tamussino K, Hanzal E, Tammaa A, Preyer O, Bader A, et al. Bleeding complications with the tension-free vaginal tape operation. Am J Obstet Gynecol. 2005;193(6):2045-9.

19. Bitan Y, Nunnally ME. Can a Log of Infusion Device Events Be Used to Understand Infusion Accidents? J Patient Saf. 4th ed. 2007;3(4):208-13.

20. DiBardino DJ, McElhinney DB, Kaza AK, Mayer JE. Analysis of the US Food and Drug Administration Manufacturer and User Facility Device Experience database for adverse events involving Amplatzer septal occluder devices and comparison with the Society of Thoracic Surgery congenital cardiac surgery databas [Internet]. 6th ed. Vol. 137, Journal of Thoracic and Cardiovascular Surgery. (C) Mosby-Year Book Inc. 2009. All Rights Reserved.: (a)Department of Cardiac Surgery, Children' s Hospital Boston, Harvard Medical School, Boston, Mass (b)Department of Cardiology, Children's Hospital Boston, Harvard Medical School, Boston, Mass; 2009. p. 1334-41.

21. Da Broi U, Adami V, Falasca E, Malangone W, Crini S, Degrassi A. A new oxygenator change-out system and procedure. Perfusion. 5th ed. 2006;21:297-303.

22. Adler DG, Conway JD, Farraye F a., Kantsevoy S V., Kaul V, Kethu SR, et al. Biliary and pancreatic stone extraction devices. Gastrointest Endosc. 2009 Oct;70(4):603-9.

23. Somberg JC, McEwen P, Molnar J. Assessment of cardiovascular and noncardiovascular medical device recalls. Am J Cardiol. 2014;113(11):1899-903.

24. Meissner B, Nelson W, Hicks R (Rod), Sikirica V, Gagne J, Schein J. The Rate and Costs Attributable to Intravenous 
Patient-Controlled Analgesia Errors. Hosp Pharm. 4th ed. 2010;44(4):312-24.

25. McCullough CE, Reed T, Kaufman-Rivi D. A Tool to Analyze Medical Device Problems: The Food and Drug Administration Device Problem Codes. J Clin Eng. 2012;37(2):56-62.

26. Greenfield LJ. Perspective from an academic on postmarket surveillance. In: Medical Device Epidemiology and Surveillance. John Wiley \& Sons, Ltd; 2007. p. 159-69.

27. Nemeth C, Nunnally M, Bitan Y, Nunnally S, Cook RI. Between choice and chance: the role of human factors in acute care equipment decisions. 2nd ed. Vol. 5, Journal of patient safety. (C) 2009 Lippincott Williams \& Wilkins, Inc.: From the Department of Anesthesia and Critical Care, Cognitive Technologies Laboratory, Chicago, Illinois.; 2009. p. 114-21.

28. Samore MH, Evans RS, Lassen A, Gould P, Lloyd J, Gardner RM, et al. Surveillance of Medical Device - Related Hazards and Adverse Events in Hospitalized Patients. Jama-Journal Am Med Assoc. 2004;291(3):325-34.

29. Brown J, Blank K. Minimally Invasive Endometrial Ablation Device Complications and Use Outside of the Manufacturers' Instructions. 4th ed. Vol. 120, Obstetrics \& Gynecology. (C) 2012 The American College of Obstetricians and Gynecologists: From the National Institute of Allergy and Infectious Diseases, Bethesda, Maryland; and the George Washington University School of Medicine, Washington, DC.; 2012. p. 865-70.

30. Gurtcheff SE. Introduction to the MAUDE database. Clin Obstet Gynecol. 1st ed. 2008 Mar;51(1):120-3.

31. Al-Safi Z a., Shavell VI, Hobson DTG, Berman JM, Diamond MP. Analysis of Adverse Events With Essure Hysteroscopic Sterilization Reported to the Manufacturer and User Facility Device Experience Database. J Minim Invasive Gynecol. 2013 Jan;20(6):825-9.

32. Stanford EJ, Paraiso MFR. A Comprehensive Review of Suburethral Sling Procedure Complications. J Minim Invasive Gynecol. 2008;15(2):132-45.

33. Clark K, Sharma D, Qin R, Chute CG, Tao C. A use case study on late stent thrombosis for ontology-based temporal reasoning and analysis. J Biomed Semantics. 2014;5(1):49.

34. Cope JU, Morrison AE, Samuels-Reid J. Adolescent use of insulin and patient-controlled analgesia pump technology: a 10-year Food and Drug Administration retrospective study of adverse events. Pediatrics. 2008;121(5):e1133-8.

35. Woo EJ. Adverse events after recombinant human BMP2 in nonspinal orthopaedic procedures general. Clin Orthop Relat Res. 2013;471(5):1707-11.
36. Zurawin RK, Zurawin JL. Adverse Events Due to Suspected Nickel Hypersensitivity in Patients with Essure Micro-Inserts. J Minim Invasive Gynecol. 2011;18(4):475-82.

37. Hankin CS, Schein J, Clark J a., Panchal S. Adverse events involving intravenous patient-controlled analgesia. 14th ed. Vol. 64, American Journal of Health-System Pharmacy. Copyright (C) 2007 American Society of Health-System Pharmacists, Inc. All rights reserved.: Cheryl S. Hankin, Ph.D., is President and Chief Scientific Officer, Biomedecon, LLC, Moss Beach, CA. Jeff Schein, Dr.P.H., is Senior Director, Ortho-McNeil Janssen Scientific Affairs, LLC, Raritan, NJ. John A. Clark, M.D., is Senior Director, Epidemiology; 2007. p. 1492-9.

38. Woo EJ. Adverse events reported after the use of recombinant human bone morphogenetic protein 2. J Oral Maxillofac Surg. 2012 Apr;70(4):765-7.

39. Wang HE, Weaver MD, Abo BN, Kaliappan R, Fairbanks RJ. Ambulance stretcher adverse events. Qual Saf Heal Care. 2009;18(3):213-6.

40. Nebeker JR, Virmani R, Bennett CL, Hoffman JM, Samore $\mathrm{MH}$, Alvarez J, et al. Hypersensitivity cases associated with drug-eluting coronary stents: A review of available cases from the Research on Adverse Drug Events and Reports (RADAR) project. J Am Coll Cardiol. 2006 Jan;47(1):175-81.

41. DeLuca L a., Simpson A, Beskind D, Grall K, Stoneking L, Stolz U, et al. Analysis of automated external defibrillator device failures reported to the food and drug administration. Ann Emerg Med. 2nd ed. 2012 Feb;59(2):103-11.

42. Alemzadeh H, Iyer RK, Kalbarczyk Z, Raman J. Analysis of safety-critical computer failures in medical devices. IEEE Secur Priv. 2013;11(4):14-26.

43. Hsi RS, Ojogho ON, Baldwin DD. Analysis of Techniques to Secure the Renal Hilum During Laparoscopic Donor Nephrectomy: Review of the FDA Database. Urology. 2009 Jul;74(1):142-7.

44. Blumenthal KB, Sutherland DE, Wagner KR, Frazier H a., Engel JD. Bladder Neck Contractures Related to the Use of Hem-O-Lok Clips in Robot-Assisted Laparoscopic Radical Prostatectomy. Urology. 2008 Jul;72(1):158-61.

45. Brown SL, Todd JF, Cope JU, Sachs HC. Breast implant surveillance reports to the U.S. Food and Drug Administration: maternal-child health problems. J Long Term Eff Med Implants. 2006;16(4):281-90.

46. Brown SL, Bright R a, Dwyer DE, Foxman B. Breast pump adverse events: reports to the food and drug administration. 2nd ed. Vol. 21, Journal of human lactation : official journal of International Lactation Consultant Association. (C)2005 International Lactation Consultant Association: S. Lori Brown 
and Roselie A. Bright are medical device epidemiologists in the Center for Devices and Radiological Health at the Food and Drug Administration, Rockville, Maryland.Diane E. Dwyer is a nurse consultant at the Food and Drug Administration and; 2005. p. 169-74.

47. Divekar a., Gaamangwe T, Shaikh N, Raabe M, Ducas J. Cardiac Perforation After Device Closure of Atrial Septal Defects With the Amplatzer Septal Occluder. ACC Curr J Rev. 2005 Apr;14(8):49.

48. Frantzides CT, Welle SN. Cardiac tamponade as a life-threatening complication in hernia repair. Surg (United States). 2012 Jul;152(1):133-5.

49. Sfyroeras GS, Koutsiaris A, Karathanos C, Giannakopoulos A, Giannoukas AD. Clinical relevance and treatment of carotid stent fractures. 5th ed. Vol. 51, Journal of Vascular Surgery. Copyright (C) by the Society for Vascular Surgery, and the North American Chapter, International Society for Cardiovascular Surgery: From the (a)Department of Vascular Surgery, University Hospital of Larissa, University of Thessaly Medical School, Larissa, Greece; (b)Laboratory for Strength of Materials and Micromechanics, Department of Civil Engineering, University of Thessaly, Volos,; 2010. p. 1280-5.

50. Tambyraja RR, Gutman M a, Megerian $\mathrm{C}$ a. Cochlear implant complications: utility of federal database in systematic analysis. 3rd ed. Vol. 131, Archives of otolaryngology--head \& neck surgery. Copyright 2005 by the American Medical Association. All Rights Reserved. Applicable FARS/DFARS Restrictions Apply to Government Use. American Medical Association, 515 N. State St, Chicago, IL 60610.: Department of Otolaryngology-Head \& Neck Surgery, Case Western Reserve University School of Medicine, University Hospitals of Cleveland, Cleveland, Ohio.; 2005. p. 245-50.

51. Boyles SH, Edwards R, Gregory W, Clark A. Complications associated with transobturator sling procedures. Int Urogynecol J Pelvic Floor Dysfunct. 2007;18(1):19-22.

52. Zelickson Z, Schram S, Zelickson B. Complications in Cosmetic Laser Surgery: A Review of 494 Food and Drug Administration Manufacturer and User Facility Device Experience Reports. Dermatologic Surg. 4th ed. 2014;40(4):378-82.

53. Chotikawanich E, Korman E, Monga M. Complications of stone baskets: 14-year review of the manufacturer and user facility device experience database. J Urol. 1st ed. 2011;185(1):179-83.

54. Hauser RG, Katsiyiannis WT, Gornick CC, Almquist AK, Kallinen LM. Deaths and cardiovascular injuries due to device-assisted implantable cardioverter-defibrillator and pacemaker lead extraction. Vol. 12, Europace. (C) Copyright Oxford University Press 2010.: Minneapolis Heart Institute
Foundation, 920 East 28th Street, Suite 300, Minneapolis, MN 55407, USA; 2010. p. 395-401.

55. Andonian S, Okeke Z, Okeke D a, Rastinehad A, Vanderbrink $\mathrm{B}$ a, Richstone L, et al. Device Failures and Patient Injuries Associated With Robot-Assisted Laparoscopic Surgeries: a Review of the Fda Database. J Urol. 2008;179(4):344.

56. Duggirala H, Herz N, Canos D, Sullivan R, Schaaf R, Pinnow E, et al. Disproportionality analysis for signal detection of implantable cardioverter-defibrillator-related adverse events in the Food and Drug Administration Medical Device Reporting System. Vol. 21. Copyright (C) 2012 John Wiley \& Sons, Inc.: (1)Division of Epidemiology, Center for Devices and Radiological Health, Food and Drug Administration, Silver Spring, MD, USA; 2012. p. 87-93.

57. Woerdeman P a, Cochrane DD. Disruption of silicone valve housing in a Codman Hakim Precision valve with integrated Siphonguard. J Neurosurg Pediatr. 2014;13(5):532-5.

58. Johnson DT, Durack JC, Fidelman N, Kerlan RK, Laberge JM. Distribution of reported starclose SE vascular closure device complications in the manufacturer and user facility device experience database. 7th ed. Vol. 24, Journal of Vascular and Interventional Radiology. (C) Copyright 2013 Society of Cardiovascular \& Interventional Radiology: (a)Department of Radiology and Biomedical Imaging, University of California, San Francisco, 505 Parnassus Avenue, Room M-361, San Francisco, CA 94143-0628(b)Department of Radiology, Memorial Sloan Kettering Cancer Center, New York, New York; 2013. p. 1051-6.

59. Hignett $S$, Griffiths P. Do split-side rails present an increased risk to patient safety? Qual Saf Heal Care. 2005;14(2):113-6.

60. Chhatriwalla AK, Cam A, Unzek S, Bhatt DL, Raymond RE, Lincoff a. M, et al. Drug-eluting stent fracture and acute coronary syndrome. Cardiovasc Revascularization Med. 2009;10(3):166-71.

61. Hauser RG, Kallinen LM, Almquist AK, Gornick CC, Katsiyiannis WT. Early failure of a small-diameter high-voltage implantable cardioverter-defibrillator lead. Hear Rhythm. 2007 Jul;4(7):892-6.

62. Hauser RG, Kallinen Retel LM. Early fatigue fractures in the IS-1 connector leg of a small-diameter ICD lead: Value of returned product analysis for improving device safety. Hear Rhythm. 2013;10(10):1462-8.

63. Metheny N, Rn P, Meert K. Effectiveness of an Electromagnetic Feeding Tube Placement Device in Detecting Inadvertent Respiratory Placement. Am J Crit Care. 3rd ed. 2014;23(3):240-8. 
64. Connell SS, Balkany TJ, Hodges A V, Telischi FF, Angeli SI, Eshraghi A a. Electrode migration after cochlear implantation. Otol Neurotol. 2nd ed. 2008;29(2):156-9.

65. Madan AK, Ternovits C a., Tichansky DS. Emerging endoluminal therapies for gastroesophageal reflux disease: adverse events. Am J Surg. 2006;192(1):72-5.

66. Della Badia C, Nyirjesy P, Atogho A. Endometrial ablation devices: Review of a manufacturer and user facility device experience database. J Minim Invasive Gynecol. 2007;14(4):436-41.

67. Liu J, Petersen BT, Tierney WM, Chuttani R, DiSario J a., Coffie JMB, et al. Endoscopic banding devices. Gastrointest Endosc. 2008 Aug;68(2):217-21.

68. Seoane-Vazquez E, Rodriguez-Monguio R, Visaria J, Carlson a. Endoscopy-related infections and toxic reactions: An international comparison. Endoscopy. 2007;39(8):742-6.

69. Erekson E a, Sung VW, Rardin CR, Myers DL. Ethylene vinyl alcohol copolymer erosions after use as a urethral bulking agent. Obstet Gynecol. 2, Part 2 ed. 2007;109(2 Pt2):490-2.

70. Dustin K. Evaluation of electromagnetic incompatibility concerns for deep brain stimulators. J Neurosci Nurs. 2008;40(5):299-303,319.

71. Hauser RG, Abdelhadi RH, McGriff DM, Kallinen Retel L. Failure of a novel silicone-polyurethane copolymer (Optim???) to prevent implantable cardioverter-defibrillator lead insulation abrasions. 2nd ed. Vol. 15, Europace : European pacing, arrhythmias, and cardiac electrophysiology : journal of the working groups on cardiac pacing, arrhythmias, and cardiac cellular electrophysiology of the European Society of Cardiology. (C) Copyright Oxford University Press 2013.: Minneapolis Heart Institute Foundation, 920 East 28th Street, Suite 500, Minneapolis, MN 55407, USA; 2013. p. 278-83.

72. Chou B, Od F. FDA-reported Adverse Events by Lens Type. CONTACT LENS Spectr. 12th ed. 2006;21(12):34.

73. Smith LP, Roy S. Fire/burn risk with electrosurgical devices and endoscopy fiberoptic cables. Am J Otolaryngol - Head Neck Med Surg. 2008 May;29(3):171-6.

74. Proctor MC, Greenfield LJ. Form and function of vena cava filters: how do optional filters measure up? Vascular. 2008;16(1):10-6.

75. Lucas SM, Pattison E a., Sundaram CP. Global robotic experience and the type of surgical system impact the types of robotic malfunctions and their clinical consequences: An FDA MAUDE review. BJU Int. 8th ed. 2012;109(8):1222-7.

76. Munro MG, Nichols JE, Levy B, Vleugels MPH, Veersema S. Hysteroscopic sterilization: 10-year retrospective analysis of worldwide pregnancy reports. J Minim Invasive Gynecol. 2014 Mar;21(2):245-51.
77. Levy R, Henderson J, Slavin K, Simpson B a., Barolat G, Shipley $\mathrm{J}$, et al. Incidence and avoidance of neurologic complications with paddle type spinal cord stimulation leads. 5th ed. Vol. 14, Neuromodulation. Copyright (C) 2011 Blackwell Publishing Ltd.: (1) Department of Neurological Surgery, University of Florida College of Medicine, Jacksonville, Florida, USA;(2) Department of Neurosurgery, Stanford University School of Medicine, Stanford, California, USA;(3) Department of Neurosurgery, University of; 2011. p. 412-22.

78. Dowdy JC, Sayre RM, Shepherd JG. Indoor tanning injuries: An evaluation of FDA adverse event reporting data. 4th ed. Vol. 25, Photodermatology Photoimmunology and Photomedicine. Copyright (C) 2009 Blackwell Publishing Ltd.: (1)Rapid Precision Testing Laboratory, Cordova, TN, USA(2)Division of Dermatology, Department of Medicine, University of Tennessee Center for the Heath Sciences, Memphis, TN, USA(3) KBD, Inc., Crescent Springs, KY, USA; 2009. p. 216-20.

79. Friedman DCW, Lendvay TS, Hannaford B. Instrument Failures for the da Vinci Surgical System: A Food and Drug Administration MAUDE Database Study. Surg Endosc Other Interv Tech. 2013;27(5):1503-8.

80. Owens C a, Bui JT, Knuttinen M-G, Gaba RC, Carrillo TC, Hoefling $\mathrm{N}$, et al. Intracardiac migration of inferior vena cava filters: review of published data. Chest. 2009;136(3):877-87.

81. Milad MP, Milad E a. Laparoscopic morcellator-related complications. J Minim Invasive Gynecol. 2014;21(3):486-91.

82. Mamas M a., Williams PD. Longitudinal stent deformation: Insights on mechanisms, treatments and outcomes from the Food and Drug Administration Manufacturer and User Facility Device Experience database. 7th ed. Vol. 8, EuroIntervention. (C) 2014 John Wiley \& Sons, Ltd: (1)Cardiovascular Institute, University of Manchester, Manchester, United Kingdom(2) Manchester Heart Centre, Manchester Royal Infirmary, United Kingdom(3)National Heart Centre Singapore, Singapore(4) Abbott Vascular, Santa Clara, California(5)Cardiovas; 2012. p. 196-204.

83. Delaney JW, Li JS, Rhodes JF. Major complications associated with transcatheter atrial septal occluder implantation: A review of the medical literature and the manufacturer and user facility device experience (MAUDE) database. Congenit Heart Dis. 2007;2(4):256-64.

84. Robinson TN, Clarke JH, Schoen J, Walsh MD. Major meshrelated complications following hernia repair: Events reported to the Food and Drug Administration. Surg Endosc Other Interv Tech. 12th ed. 2005;19(12):1556-60.

85. Manoucheri E, Fuchs-Weizman N, Cohen SL, Wang KC, Einarsson J. MAUDE: Analysis of Robotic-Assisted Gynecologic Surgery. J Minim Invasive Gynecol. 2014 Jul;21(4):592-5. 
86. Hsi RS, Saint-Elie DT, Zimmerman GJ, Baldwin DD. Mechanisms of Hemostatic Failure During Laparoscopic Nephrectomy: Review of Food and Drug Administration Database. Urology. 2007;70(5):888-92.

87. Badlani G, Shah H. Mesh complications in female pelvic floor reconstructive surgery and their management: A systematic review. Indian J Urol. 2012 Apr;28(2):129.

88. Rodriguez S a., Adler DG, Chand B, Conway JD, Diehl DL, Kantsevoy S V., et al. Mucosal ablation devices. Gastrointest Endosc. 2008 Dec;68(6):1031-42.

89. Lipka S, Kumar A, Richter JE. No Evidence for Efficacy of Radiofrequency Ablation for Treatment of Gastroesophageal Reflux Disease: A Systematic Review and Meta-Analysis. Clin Gastroenterol Hepatol. 2014;13(6):1058-67.

90. Pokorney SD, Greenfield RA, Atwater BD, Daubert JP, Piccini JP. Novel mechanism of premature battery failure due to lithium cluster formation in implantable cardioverter-defibrillators. Heart Rhythm. 2014;11(12):2190-5.

91. Schein JR, Hicks RW, Nelson WW, Sikirica V, Doyle DJ. Patient-controlled analgesia-related medication errors in the postoperative period: Causes and prevention. Drug Saf. 2009;32(7):549-59.

92. Cope JU, Samuels-Reid JH, Morrison a E. Pediatric use of insulin pump technology: a retrospective study of adverse events in children ages 1-12 years. J Diabetes Sci Technol. 2012 Sep;6(5):1053-9.

93. Deng DY, Rutman M, Raz S, Rodriguez L V. Presentation and management of major complications of midurethral slings: Are complications under-reported? Neurourol Urodyn. 2007;26(1):46-52.

94. Shellock FG, Crivelli R, Venugopalan R. Programmable infusion pump and catheter: Evaluation using 3-Tesla magnetic resonance imaging. Neuromodulation. 2008;11(3):163-70.

95. Englum BR, Pavlisko EN, Mack MC, Ganapathi AM, Schechter M a, Hanna JM, et al. Pseudoaneurysm Formation After Medtronic Freestyle Porcine Aortic Bioprosthesis Implantation: A Word of Caution. Ann Thorac Surg. 2014 Dec;98(6):2061-7.

96. Shah JS, Maisel WH. Recalls and safety alerts affecting automated external defibrillators. [Internet]. 6th ed. Vol. 296, JAMA : the journal of the American Medical Association. Copyright 2006 by the American Medical Association. All Rights Reserved. Applicable FARS/DFARS Restrictions Apply to Government Use. American Medical Association, 515 N. State St, Chicago, IL 60610.: Cardiovascular Division, Department of Medicine, Beth Israel Deaconess Medical Center and Harvard Medical School, Boston, Mass.; 2006. p. 655-60.
97. Woo EJ. Recombinant human bone morphogenetic protein-2: Adverse events reported to the Manufacturer and User Facility Device Experience database. Spine J. 2012;12(10):894-9.

98. Davis ID, Cizman B, Mundt K, Wu L, Childers R, Mell R, et al. Relationship between drain volume/fill volume ratio and clinical outcomes associated with overfill complaints in peritoneal dialysis patients. Perit Dial Int. 2011;31(2):148-53.

99. Meng M V. Reported failures of the polymer self-locking (Hem-o-lok) clip: review of data from the Food and Drug Administration. J Endourol. 2006;20(12):1054-7.

100.Patel A a, Brodke DS, Pimenta L, Bono CM, Hilibrand AS, Harrop JS, et al. Revision strategies in lumbar total disc arthroplasty. Spine (Phila Pa 1976). 11th ed. 2008;33(11):1276-83.

101. Hauser RG, McGriff D, Retel LK. Riata implantable cardioverterdefibrillator lead failure: Analysis of explanted leads with a unique insulation defect. Hear Rhythm. 2012 May;9(5):742-9.

102. Muscarella LF. Risk of transmission of carbapenem-resistant Enterobacteriaceae and related "superbugs" during gastrointestinal endoscopy. World J Gastrointest Endosc. 2014 Oct;6(10):457.

103. Hoffer EK, Gemery JM. Roadmap Guidance for the Safer Deployment of an Arterial Closure Device. J Vasc Interv Radiol. 2009 Sep;20(9):1244-7.

104. Sambrook A, Cooper KG. Second-generation treatment: microwave. Best Pract Res Clin Obstet Gynaecol. 2007 Dec;21(6):969-77.

105. Kramer DB, Baker M, Ransford B, Molina-Markham A, Stewart Q, Fu K, et al. Security and privacy qualities of medical devices: An analysis of FDA postmarket surveillance. PLoS One. 2012;7(7):e40200.

106. Brott BC, Anayiotos AS, Chapman GD, Anderson PG, Hillegass WB. Severe, diffuse coronary artery spasm after drug-eluting stent placement. J Invasive Cardiol. 2006 Dec;18(12):584-92.

107. Shah RJ, Somogyi L, Petersen BT, Tierney WM, Adler DG, Chand B, et al. Short-wire ERCP systems. Gastrointest Endosc. 2007;66(4):650-7.

108. Adlakha S, Sheikh M, Wu J, Burket MW, Pandya U, Colyer $\mathrm{W}$, et al. Stent fracture in the coronary and peripheral arteries. J Interv Cardiol. 4th ed. 2010;23(4):411-9.

109. Mamas M a., Foin N, Abunassar C, Khan M a., Di Mario C, Fraser DG. Stent fracture: Insights on mechanisms, treatments, and outcomes from the food and drug administration manufacturer and user facility device experience database. Catheter Cardiovasc Interv. 2014;83(7):E251-9.

110.Zellner C, Ports T a., Yeghiazarians Y, Boyle AJ. Sterile radial artery granuloma after transradial procedures: A unique and avoidable complication. 5th ed. Vol. 76, Catheterization and 
Cardiovascular Interventions. Copyright (C) 2010 John Wiley \& Sons, Inc.: (1) Division of Cardiology, Department of Medicine, University of California San Francisco, San Francisco, California; 2010. p. 673-6.

111. Angel LF, Tapson V, Galgon RE, Restrepo MI, Kaufman J. Systematic review of the use of retrievable inferior vena cava filters. 11th ed. Vol. 22, Journal of vascular and interventional radiology : JVIR. (C) Copyright 2011 Society of Cardiovascular \& Interventional Radiology: (a)Division of Pulmonary and Critical Care Medicine, University of Texas Health Science Center at San Antonio, 7703 Floyd Curl Drive, San Antonio, TX 78229(b)Division of Pulmonary, Allergy and Critical Care Medicine, Duke University Medical Center, Durha; 2011. p. 1522-1530.e3.

112. Blumenthal SL, Guyer RD, Geisler FH, McAfee PC, Regan JJ. The First 18 Months Following Food and Drug Administration Approval of Lumbar Total Disc Replacement in the United States: Reported Adverse Events Outside an Investigational Device Exemption Study Environment. SAS J. 2007 Mar;1(1):8-11.

113. Balkany TJ, Whitley M, Shapira Y, Angeli SI, Brown K, Eter E, et al. The temporalis pocket technique for cochlear implantation: an anatomic and clinical study. Otol Neurotol. 2009;30(7):903-7.

114. Nunnally ME, Bitan Y. Time to Get Off this Pig's Back? 3rd ed. Vol. 2, Journal of Patient Safety. (C) 2006 Lippincott Williams \& Wilkins, Inc.; 2006. p. 124-31.

115. Causon A, Verschuur C, Newman T a. Trends in cochlear implant complications: implications for improving long-term outcomes. Otol Neurotol. 2nd ed. 2013;34(2):259-65.

116. Fuller J, Ashar BS, Carey-Corrado J. Trocar-associated injuries and fatalities: An analysis of 1399 reports to the FDA. J Minim Invasive Gynecol. 2005;12(4):302-7.

117. Magrabi F, Ong M-S, Runciman W, Coiera E. Using FDA reports to inform a classification for health information technology safety problems. J Am Med Informatics Assoc. 1st ed. 2012;19(1):45-53.

118. Malgor RD, Labropoulos N. A systematic review of symptomatic duodenal perforation by inferior vena cava filters. J Vasc Surg. 2012 Mar;55(3):856-861.e3.

119. Santini F, Onorati F, Rapetto F, Passerone G, Faggian G, Mazzucco A. Cardiac Perforation by Atrial Septal Defect Closure Devices. JACC Cardiovasc Interv. 2014;7(3):338.

120. Banerjee S, Cherian JJ, Bono J V, Kurtz SM, Geesink R, Meneghini RM, et al. Gross Trunnion Failure After Primary Total Hip Arthroplasty. J Arthroplasty. 2014;30(4):641-8.
121.Elnitsky CA, Lind JD, Rugs D, Powell-Cope G. Implications for patient safety in the use of safe patient handling equipment: A national survey. Int J Nurs Stud. 2014 Dec;51(12):1624-33.

122. Contractor S, Esmaeili A, Reina D, Deitch E. Incomplete deployment of the Vena Tech LP filter--case series and concerns. Vasc Endovascular Surg. 2011;45(4):345-51.

123. Stroud NJ, DiPaola MJ, Martin BL, Steiler C a, Flurin P-H, Wright TW, et al. Initial glenoid fixation using two different reverse shoulder designs with an equivalent center of rotation in a low-density and high-density bone substitute. J Shoulder Elb Surg. 2013 Nov;22(11):1573-9.

124. Sticherling $\mathrm{C}$, Burri $\mathrm{H}$. Introduction of new industry standards for cardiac implantable electronic devices: Balancing benefits and unexpected risks. 8th ed. Vol. 14, Europace. (C) Copyright Oxford University Press 2012.: (1)Department of Cardiology, The University Hospital of Basel, Basel, Switzerland(2)The University Hospital of Geneva, Geneva, Switzerland; 2012. p. 1081-6.

125. Galhotra S, Amesur NB, Zajko a B, Simmons RL. Migration of the Gunther Tulip inferior vena cava filter to the chest. J Vasc Interv Radiol. 12th ed. 2007;18(12):1581-5.

126. Cvach M. Monitor alarm fatigue: An integrative review. Biomed Instrum Technol. 4th ed. 2012;46(4):268-77.

127. Mandl KD, McNabb M, Marks N, Weitzman ER, Kelemen S, Eggleston EM, et al. Participatory surveillance of diabetes device safety: a social media-based complement to traditional FDA reporting. J Am Med Inform Assoc. 4th ed. 2014;21(4):687-91.

128. Sobol WT. Recent advances in MRI technology: Implications for image quality and patient safety. Saudi J Ophthalmol. 2012 Oct;26(4):393-9.

129. Murphy BP, Breen LT. The Design of an Improved Force Focused Angioplasty Catheter. J Med Device. 2013;8(1):011007.

130. Yustein AS, Schultz D, Neuland C, Buckles DS, Nipper JC, Stephenson R a., et al. U.S. Food and Drug Administration and off-label use of expandable metal biliary stents within the peripheral vasculature. Vol. 19, Journal of vascular and interventional radiology : JVIR. (C) Copyright 2008 Society of Cardiovascular \& Interventional Radiology: Center for Devices and Radiological Health, U.S. Food and Drug Administration, HFZ-400, 9200 Corporate Blvd, Rockville, MD 20850.; 2008. p. 965-9.

131. Chai KEK, Anthony S, Coiera E, Magrabi F. Using statistical text classification to identify health information technology incidents. J Am Med Inform Assoc. 5th ed. 2013;20(5):980-5.

132. Connor VF. Essure: A Review Six Years Later. J Minim Invasive Gynecol. 2009 May;16(3):282-90. 
133. Glasser MH. Practical Tips for Office Hysteroscopy and Second-Generation "Global” Endometrial Ablation. J Minim Invasive Gynecol. 2009 Jul;16(4):384-99.

134.Crnich CJ, Halfmann J a, Crone WC, Maki DG. The effects of prolonged ethanol exposure on the mechanical properties of polyurethane and silicone catheters used for intravascular access. Infect Control Hosp Epidemiol. 8th ed. 2005;26(8):708-14.

135.Falk GW, Fennerty MB, Rothstein RI. AGA Institute Technical Review on the Use of Endoscopic Therapy for Gastroesophageal Reflux Disease. Gastroenterology. 2006 Oct;131(4):1315-36.

136. Regulation (EU) $2017 / 745$ of the European Parliament and of the Council of 5 April 2017 on medical devices, amending Directive 2001/83/EC, Regulation (EC) No 178/2002 and Regulation (EC) No 1223/2009 and repealing Council Directives 90/385/EEC and 93/42/EEC.

137. Regulation (EU) 2017/746 of the European Parliament and of the Council of 5 April 2017 on in vitro diagnostic medical devices and repealing Directive 98/79/EC and Commission Decision 2010/227/EU.

138. Malataras P., Pallikarakis N. (2016) Comparing the EU and USA Medical Devices Vigilance Systems Transparency. In: Kyriacou E., Christofides S., Pattichis C. (eds) XIV Mediterranean Conference on Medical and Biological Engineering and Computing 2016. IFMBE Proceedings, vol 57. pp 1061-1065, Springer, Cham

139. Bliznakov Z, Stavrianou K, Pallikarakis N. Medical devices recalls analysis focusing on software failures during the last decade. IFMBE Proc. 2014;41:1174-7.

140.Pallikarakis N. Medical Devices Software. In: Proceedings of the Medical Device Software Workshop, EC Joint Research Centre, Ispra, Italy. 2003.

141. Bliznakov Z, Mitalas G, Pallikarakis N. Analysis and classification of medical device recalls. In: World congress on 